\title{
ACUTE POSTSURGICAL SUPPURATIVE PAROTITIS: CURRENT PREVALENCE AT HOSPITAL DAS CLÍNICAS, SÃO PAULO UNIVERSITY MEDICAL SCHOOL
}

\begin{abstract}
SUMMARY
Postsurgical acute suppurative parotitis is a bacterial gland infection that occurs from a few days up to some weeks after abdominal surgical procedures. In this study, the authors analyze the prevalence of this complication in Hospital das Clínicas/São Paulo University Medical School by prospectively reviewing the charts of patients who underwent surgeries performed by the gastroenterological and general surgery staff from 1980 to 2005. Diagnosis of parotitis or sialoadenitis was analyzed. Sialolithiasis and chronic parotitis previous to hospitalization were exclusion criteria. In a total of 100,679 surgeries, 256 patients were diagnosed with parotitis or sialoadenitis. Nevertheless, only three cases of acute postsurgical suppurative parotitis associated with the surgery were identified giving an incidence of $0.0028 \%$. All patients presented with risk factors such as malnutrition, immunosuppression, prolonged immobilization and dehydration. In the past, acute postsurgical suppurative parotitis was a relatively common complication after major abdominal surgeries. Its incidence decreased as a consequence of the improvement of perioperative antibiotic therapy and postoperative support. In spite of the current low incidence, we believe it is important to identify risks and diagnose as quick as possible, in order to introduce prompt and appropriate therapeutic measures and avoid potentially fatal complications with the evolution of the disease.
\end{abstract}

KEYWORDS: Acute parotitis; Post surgical; Bacterial gland infection.

\section{INTRODUCTION}

The parotid salivary gland is the gland most frequently affected by inflammatory or infectious processes. Acute postsurgical suppurative parotitis was a common complication of abdominal surgeries before the routine introduction of perioperative antibiotic therapy. Nowadays, it is considered a rare condition affecting only $0.02 \%$ to $0.04 \%$ of patients within the first 15 postoperative weeks with a peak between the $5^{\text {th }}$ and $7^{\text {th }}$ postoperative day ${ }^{1,2,14}$. Among known risk factors, old age, immunosuppression, malnutrition and diabetes mellitus 7 seem to be the most important ${ }^{8,13}$. Although usually confined to the parotid gland, infection may spread to cervical fascial planes and mediastinum ${ }^{1}$. Acute suppurative parotitis (ASP) is a bacterial sialoadenitis that ascends from the Stenson's duct into the parotitis parenchyma ${ }^{17}$.

After surgery, patient immobilization, prolonged fasting, bad oral hygiene and decreases in salivary secretion can determine the onset of sialolithiasis with consequent stasis and an ascending infection ${ }^{16,17}$. Salivary stasis can also be observed in postoperative patients due to dehydration that occurs with blood and fluid loss during surgery. In addiction, commonly prescribed drugs can cause a decrease in salivary production, in particular antidepressive, anticholinergic and diuretic agents ${ }^{17}$. The patient's position also plays an important role because head inflection and inclination of patients submitted to neurosurgical procedures are a predisposing factor ${ }^{2,16}$.

ASP is generally caused by S. aureus and Streptococcus sp., although enterobacteria, anaerobes and fungi are also implicated ${ }^{3,6,8}$. The characteristic clinical symptoms are the sudden appearance of pain, hyperemia and progressive edema in the parotid gland region. Edema or hardening of mouth floor and tongue base may be evident on physical examination. Ultrasonography or computed tomography confirm diagnosis ${ }^{4,15}$. ASP may progress to local abscess formation which in turn may lead to salivary duct obstruction, osteomyelitis of adjacent facial bones, mediastinitis and sepsis ${ }^{1,4,6,8}$.

Recommended treatment is wide-spectrum oral antibiotics associated to abscess drainage when necessary. Cultures obtained from the Stensen's duct or directly from the gland may determine appropriate antibiotic therapy. In some cases, external drainage of the parotid gland is recommended.

The aim of this article is to evaluate the incidence, predisposing factors, treatment and evolution of ASP in a tertiary university hospital.

(1) Surgery Department, Vascular Surgery Division, Hospital das Clínicas/University of São Paulo Medical School, São Paulo, SP, Brazil.

(2) Gastroenterology Department, Digestive Tract Surgery Division, Hospital das Clínicas/University of São Paulo Medical School, São Paulo, SP, Brazil

(3) Surgery Department, General Surgery Division, Hospital das Clínicas/University of São Paulo Medical School, São Paulo, SP, Brazil.

(4) Surgery Department, Faculdade de Ciências Médicas da Santa Casa de São Paulo, São Paulo, SP, Brazil.

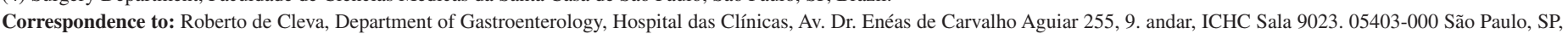
Brasil. Tel: +55.11.3069-6876. E-mail: roberto.cleva@hcnet.usp.br; belczak@gmail.com 


\section{PATIENTS AND METHODS}

We evaluated the charts of all patients submitted to surgeries performed by the Gastroenterological and General Surgery Divisions of Hospital das Clínicas - São Paulo University Medical School from 1980 to 2005. The charts of patients with the diagnosis of parotitis or sialoadenitis as surgical complications were selected. Sialolithiasis and chronic parotitis prior to hospitalization were exclusion criteria. The presence of systemic diseases and any other predisposing factors for parotitis, including immunosuppression, malnutrition, dehydration, use of perioperative antibiotic therapy and prolonged stasis, were evaluated.

\section{RESULTS}

Two hundred and fifty-six charts of patients with parotitis or sialoadenitis were identified among the 106,790 surgical procedures performed over the last 25 years. Two hundred and fifty-three patients were excluded from the analysis as sialolithiasis or chronic parotitis was diagnosed prior to hospitalization. Only three cases of acute postsurgical suppurative parotitis were considered, giving an incidence of $0.0028 \%$. The clinical characteristics, medications, relevant laboratory examinations, surgical procedures and other relevant factors of these patients are shown in Table 1.

\section{DISCUSSION}

A very low incidence $(0.0028 \%)$ of ASP exclusively associated with abdominal surgeries was observed over the last 25 years in this hospital; roughly ten-fold less than figures quoted in the literature ${ }^{1,2,14,15}$. The reported cases showed clinical, laboratory and ultrasound findings typical of the disease ${ }^{3}$. All the patients presented systemic debilitating diseases and various predisposing factors for the development of ASP (Table 1).

Prolonged bed rest, common after major abdominal surgical procedures, which is considered a predisposing risk factor for $\mathrm{ASP}^{2}$, were observed in all patients. All patients were over 60 years old and had relevant nutritional deficits, characterized by a malnourished aspect, recent considerable weight loss and hypoalbuminemia. Patient 1 presented with chronic renal failure and Patient 3, diabetes mellitus ${ }^{7}$, which are known to be immunosuppressive states.

Some prescribed drugs may cause dehydration (such as diuretic agents in Patients 1 and 3), and additionally, Patient 1 had significant bleeding on the $7^{\text {th }}$ postoperative day.

Patient 2 did not receive cephazolin-based prophylaxis before the

Table 1

Clinical characteristics, medications, relevant laboratory examinations, abdominal surgery, infectious agents isolated and treatment of three patients with acute postsurgical suppurative parotitis in our hospital

\begin{tabular}{|c|c|c|c|}
\hline & Case 1 - 65 years old, male & Case 2 - 61 years old, female & Case 3 - 74 years old, male \\
\hline Clinical symptoms & $\begin{array}{l}\text { Abrupt growth, edema and } \\
\text { hyperemia of left infra-auricular } \\
\text { region to the jaw's angle, and } \\
\text { fever }\left(37.9^{\circ} \mathrm{C}\right)\end{array}$ & $\begin{array}{l}\text { Hyperemia, edema and right } \\
\text { parotid region hardening, no fever }\end{array}$ & $\begin{array}{l}\text { Hyperemia and edema of the jaw's } \\
\text { angle, in left parotid region, fever } \\
38.3^{\circ} \mathrm{C}\end{array}$ \\
\hline $\begin{array}{l}\text { Previous surgical } \\
\text { treatment }\end{array}$ & $\begin{array}{l}\text { Total gastrectomy with D2 } \\
\text { lymphadenectomy }\end{array}$ & Right hemicolectomy & $\begin{array}{l}\text { Intestinal restoration post- } \\
\text { Hartmann for intestinal ischemia }\end{array}$ \\
\hline Comorbidities & $\begin{array}{l}\text { Renal insufficiency, hypertension, } \\
\text { malnutrition, neoplasia }\end{array}$ & $\begin{array}{l}\text { Malnutrition, neoplasia, } \\
\text { smoking }\end{array}$ & $\begin{array}{l}\text { Hypertension, diabetes, } \\
\text { dyslipidemia, malnutrition, } \\
\text { smoking, systemic atherosclerosis }\end{array}$ \\
\hline $\begin{array}{l}\text { Laboratory exams } \\
\text { (on diagnosis of parotitis) }\end{array}$ & $\begin{array}{l}\text { Albumin } 2.84 \mathrm{~g} / \mathrm{dL} \\
\mathrm{Hb} 8.5 \mathrm{~g} / \mathrm{dL} \\
\text { Creatinine } 3.3 \mathrm{mg} / \mathrm{dL} \\
\text { Urea } 124 \mathrm{mg} / \mathrm{dL} \\
\text { Leukocytes } 14.6 \times 10^{3} \mathrm{~mm}^{3} \\
\text { Amylase } 1014 \mathrm{IU} / \mathrm{dL}\end{array}$ & $\begin{array}{l}\text { Albumin } 3.04 \mathrm{~g} / \mathrm{dL} \\
\mathrm{Hb} 9.0 \mathrm{~g} / \mathrm{dL} \\
\text { Leukocytes } 16.8 \times 10^{3} \mathrm{~mm}^{3} \\
\text { Amylase } 315 \mathrm{IU} / \mathrm{dL}\end{array}$ & $\begin{array}{l}\text { Albumin } 3.6 \mathrm{~g} / \mathrm{dL} \\
\mathrm{Hb} 10.6 \mathrm{~g} / \mathrm{dL} \\
\text { Glycemia } 216 \mathrm{mg} / \mathrm{dL} \\
\text { Leukocytes } 20.32 \times 10^{3} \mathrm{~mm}^{3} \\
\text { Amylase } 625 \mathrm{IU} / \mathrm{dL}\end{array}$ \\
\hline $\begin{array}{l}\text { Medications } \\
\text { (during hospitalization) }\end{array}$ & $\begin{array}{l}\text { Amlodipine, hydrochlorothiazide, } \\
\text { furosemide, } 3 \mathrm{U} \text { of packed red } \\
\text { blood cells, dipyrone, tramal, } \\
\text { morphine }\end{array}$ & $\begin{array}{l}20 \% \text { NPP - } 10 \text { days, tramal, } \\
\text { dipyrone, Ketoprofen }\end{array}$ & $\begin{array}{l}\text { Captopril, AAS, Regular } \\
\text { Insulin, dipyrone, tramal, } \\
\text { codeine, atenolol, simvastatin, } \\
\text { hydrochlorothiazide }\end{array}$ \\
\hline $\begin{array}{l}\text { Isolated agents and } \\
\text { antibiotic used }\end{array}$ & $\begin{array}{l}\text { Blood culture: } \\
\text { Staphylococcus aureus } \\
\text { Vancomycin }\end{array}$ & $\begin{array}{l}\text { Negative cultures } \\
\text { Vancomycin }\end{array}$ & $\begin{array}{l}\text { Blood culture: } \\
\text { Staphylococcus aureus } \\
\text { Vancomycin }\end{array}$ \\
\hline $\begin{array}{l}\text { Antibiotic prophylaxis } \\
\text { with cephazolin }\end{array}$ & Yes & No & Yes \\
\hline $\begin{array}{l}\text { Diagnosis of ASP: } \\
\text { postoperative day }\end{array}$ & $3^{\text {rd }}$ & $4^{\text {th }}$ & $13^{\text {th }}$ \\
\hline
\end{tabular}


surgical procedure because it was not routinely recommended in the past; nowadays however, this is a common practice in order to avoid infections after surgical manipulation ${ }^{10}$.

Thus, all three patients presented with important risk factors for ASP: malnutrition, immunosuppression, prolonged bed rest and dehydration. Despite being uncommon, ASP was diagnosed based on clinical and laboratorial findings in all three patients. The patients were diagnosed with pain, hyperemia, localized edema together with leukocytosis and hyperamylasemia in laboratory examinations. All patients responded well to empiric antibiotic treatment using vancomycin, although no cultures were isolated from infected sites. Staphylococcus aureus was isolated from blood cultures in two patients. Surgical interventions, such as incision and drainage, as recommended when antibiotic therapy fails, were not necessary for these patients. Previously reported complications, including necrotizing fasciitis and mediastinitis, were not observed. All three patients where discharged from the hospital in good clinical conditions.

Acute postsurgical suppurative parotitis used to be a relatively common complication in major abdominal surgeries. Currently its incidence has decreased as a consequence of antibiotic prophylaxis, improvement of preoperative preparation, surgical conditions, and postoperative support. In spite of this current low incidence, we consider it to be important to identify the risks, as well as to diagnose the condition as soon as possible in order to begin appropriate therapeutic measures and prevent serious complications.

\section{RESUMO}

Parotidite aguda pós-cirúgica: prevalência atual no Hospital das Clínicas da Faculdade de Medicina da Universidade de São Paulo

A parotidite supurativa pós-cirúrgica é infecção bacteriana da glândula que ocorre poucos dias até algumas semanas após procedimento cirúrgico. Os autores analisam a prevalência desta complicação cirúrgica nos últimos 25 anos do Hospital das Clínicas de São Paulo. Foram analisados os prontuários das cirurgias realizadas pelos serviços de Cirurgia do Aparelho Digestivo e Cirurgia Geral da Faculdade de Medicina da Universidade de São Paulo no período de 1980 a 2005, num total de 106790 cirurgias. Todos os prontuários que apresentaram entre os diagnósticos das altas complicações cirúrgicas, parotidite ou sialoadenite foram avaliados. Foram identificados 256 prontuários. Pacientes com outras complicações, ou que já apresentavam sialolitíase ou parotidite crônica anterior à internação foram excluídos do estudo. Foram identificados apenas três casos de parotidite aguda supurativa pós-cirúrgica, revelando incidência de $0,0028 \%$. A parotidite supurativa pós-cirúrgica foi complicação relativamente comum de grandes cirurgias abdominais no passado, com acentuada redução atual da sua incidência decorrente da antibioticoterapia de amplo espectro, além de preparação pré-operatória adequada e suporte pós-operatório dos pacientes. Apesar da baixa incidência atual, consideramos importante identificar seus fatores de risco, assim como realizar diagnóstico precoce, conduta terapêutica apropriada para evitar complicações letais associadas a esta infecção.

\section{REFERENCES}

1. ARONIN, A.E; ASS, B.L.U. \& SHARAPOVA, O.K. - Surgical staphylococcal sepsis. Klin. Khir., 9: 64-66, 1969.

2. AULMANN, J. - Prevention of oral candidiasis and parotitis. The importance of oral hygiene is often underrated. Pflege Z., 48: 597-600, 1995

3. BROMIG, G. - Frequency and treatment of postoperative parotitis in the last 22 years at the surgical University Clinic Frankfurt on Main. Langenbecks Arch. Chir., 322: 772-774, 1968.

4. FATTAHI, T.T.; LYU, P.E. \& VAN SICKELS, J.E. - Management of acute suppurative parotitis. J. oral Maxillofac. Surg., 60: 446-448, 2002.

5. KLEMENTOV, A.V. \& GURVICH, S.E. - Acute suppurative parotitis after surgery of the peritoneal cavity. Vestn. Khir. Im. I I Grek., 101: 28-31, 1968.

6. KNEPIL, G.J. \& FABBRONI, G. - A life threatening complication of acute parotitis Brit. J. oral Maxillofac. Surg., 46: 328-329, 2008.

7. KRIVOLUTSKAIA, E.G. \& SAKOVICH, A.A. - The clinical picture of acute parotitis developing in patients following abdominal surgery. Vestn. Khir. Im. I I Grek., 109: $56-57,1972$

8. LUNIN, S.D. \& MOLL, S. - Images in clinical Medicine. Suppurative parotitis. New Engl. J. Med., 345: 662, 2001.

9. MARTIS, C. - Septic postoperative parotitis. Stomatol. Chron. (Athenai), 12: 41-50, 1968.

10. MAUSBACH, H. \& RAUCH, K.D. - Clinical observations and treatment experiences in postoperative parotitis. Med. Welt, 15: 953-958, 1968.

11. McANALLY, T. - Parotitis: clinical presentation and management. Postgrad. Med., 71: 87-93, 97-99, 1982.

12. MEDEIROS, A.C.; AIRES NETO, T.; DANTAS FILHO, A.M. et al. - Infecção hospitalar em pacientes cirúrgicos de hospital universitário. Acta Cir. bras., 18(supl. 1): $15-18,2003$

13. MOLCHANOVA, K.A. \& KARANDASHOV, V.I. - Clinical death and resuscitation in severe odontogenic inflammatory processes. Stomatologiia (Mosk.), 57: 39-41, 1978

14. ROBINSON, J.R. - Surgical parotitis: a vanishing disease. Surgery, 39: 703-707, 1955

15. SAPOZHNIKOV, V.M. - Clinical aspects and treatment of postoperative parotitis. Vestn. Khir. Im. I I Grek., 121: 42-45, 1978.

16. SERVIÁ GOIXART, L.; BADÍA, M.; CAMPI, D. et al. - Parotiditis aguda tras traqueotomia en cuidados intensivos. Med. Intens., 30: 26-29, 2006.

17. TEUBNER, E. - Contribution to the pathomorphology and pathogenesis of postoperative parotitis. Bruns' Beitr. klin. Chir., 216: 404-413, 1968.

Received: 12 March 2007

Accepted: 3 September 2008 